\title{
FORENSIC MEDICAL EXAMINATTION OF LIVING PERSONS IN CASES OF INJURY OF THE EXTERNAL RESPIRATORY ORGANS
}

\author{
Olkhovsky Vasil, Gubin Mykola, Grygorian Edgar
}

Kharkiv National Medical University

https://doi.org/10.35339/ic.8.2.95-99

\begin{abstract}
Background. Trauma of external respiratory organs in victims is often a reason for the referral to forensic medical examination by law enforcement. The purpose of this work was to analyze the peculiarities of formation of forensic medical expert conclusion, based on the results of determining the gravity of bodily injuries in victims with closed trauma of the organs external respiration, depending on their morphological and clinical characteristics and gravity, to find the ways to unify expert assessment. Subjects and Methods. 183 conclusions of forensic medical examination in Kharkiv Regional Expert Institution, on the cases of a closed blunt trauma of the organs of external respiration, were analyzed. Results. According to the mechanism of bodily injuries, in 171,1 (93,4\%) cases there was an impact of blunt solid objects on the neck and chest, in $11(6 \%)$ cases there was a compression of the neck by hands or other blunt solid objects, in $1(0,5 \%)$ case - a compression of the neck by hands and a loop. At the given trauma, modern experts' approaches to an assessment of bodily injuries were defined. Severe bodily injuries were defined in $17(9,3 \%)$ cases of trauma, with the emergence of life-threatening events such as acute respiratory failure, traumatic shock, mechanical asphyxia. Moderate bodily injuries were determined by experts in the 151 $(82,5 \%)$ cases, mostly injuries from fractures of ribs and cartilage of the larynx, at absence danger to life. Light bodily injuries were determined by experts in $15(8,2 \%)$ cases of mostly laryngeal injuries, complicated by its post-traumatic inflammation. The absence of unified scientific and methodological approach for the objective assessment of injuries of the external respiratory system organs has been defined. Conclusions. When conducting a forensic medical assessment of such injuries, there are cases of both underestimation and overestimation of the gravity of bodily injuries. According to the results of the performed investigation, further ways to unify morphological and clinical approaches at forensic-medical assessment of these bodily injuries were defined.
\end{abstract}

Keywords: forensic medical examination, trauma of external respiratory organs, diagnostic criteria, severity of body injuries.

\section{Introduction}

Forensic medical conclusion is drawn up by experts due to referral of living persons to determine severity of bodily injuries to the relevant expert institutions, namely the bureau of forensic medical examination of the Ministry of Health of Ukraine [1]. According to the legislation of Ukraine, severity of bodily injuries may be defined as severe, moderate, or light, according to the

Corresponding Author:

Edgar Grygorian, MD, PhD student

of the Department of Forensic Medicine,

Medical Law named after prof. M.S. Bokarius,

Kharkiv National Medical University,

Kharkiv, Ukraine.

E-mail: 8520148@gmail.com criteria of "Rules for forensic medical assessment of bodily injuries severity" (1995) [2]. Thus, the main criterion of severe injury is a "danger to life", moderate - "health disorder lasting more than 21 days", light injury - "short-term disorders of health, less than three weeks," or minor transient effects up to 6 days [3]. Determining severity of bodily injuries to the victim is necessary for judicial investigating agencies to determine the extent of criminal liability of the attacker for the injury. Especially important it becomes when causing the victim of closed blunt trauma of the external respiratory organs (ERO) [4-7]. This is due to the fact that such injuries most often affect vital organs, like the airways, chest, lungs, ribs, intercostal muscles, which requires appropriate expert qualifications [8-11]. 
Our study of the literature in this field $[1,3,6$, 12-16] showed that experts do not have a single scientific and methodological approach to determining the severity of these injuries ERO. In some cases, according to the opinion of some scientists, it is appropriate to use only morphological approach in which the morphology of the existing injury could already define damage as severe, lifethreatening $[6,12,14]$. In other cases, a clinical and morphological approach is used, in which the severity of the injury is clinical, including functional signs of morphologically determined by the expert damage, which indicate a threat to life $[1,3,13]$. In the absence of these clinical signs, the expert must apply other criteria for the severity of injuries.

According to the "Rules ..." , a closed blunt trauma of ERO may be qualified as severe damage only in cases of presence the lifethreatening events listed in p. 2.1.3 "o" [2] .

\section{Purposes, subjects and methods:}

2.1. Purpose: to analyze the peculiarities of forensic medical expert conclusion formation based on the results of determining the gravity of bodily injuries in victims with closed trauma of the organs external respiration depending on their morphological and clinical characteristics and gravity to find the ways to unify expert assessment.

\subsection{Subjects \& Methods}

The materials for our work were retrospective analysis of 44000 conclusions of forensic medical examinations for seven years, carried out in the department of examination victims, accused and other persons of Kharkiv Regional Bureau of Forensic Medical Examination (KRBFME). In total, 183 cases of forensic medical examination of closed blunt trauma ERO were processed. The study was retrospective. During our work, we have used the following methods: registration method - the data was written on a specially designed registration card; methods of descriptive statistics; morphological and clinical method - the nature of injuries and clinical signs of dysfunction of injured organs were determined; forensic medical - the bodily injuries severity, evaluated by experts, and used the qualifying features was analyzed. This study was permitted by the ethics and bioethics commis-sion of Kharkiv National Medical University. During examination, oral consent was obtained from all victims. The written consent from victims during forensic medical examinations should not be provided, according to regulatory documents governing their performance.

\section{Results \& Discussion}

The analysis of the carried observations has presented that in the department of examination of victims, accused and others persons of KRBFME, cases of the ERO blunt trauma examinations were $0,5 \%$ of the total annual quantity of expert examinations. Traumas of ERO were more frequent in males (69\% of cases), more than half of victims ( $52 \%$ of cases) were of working age $-20-50$ years. Mainly, domestic conflicts lead to ERO injuries. It should be noted that a rare occurrence of such injuries was also noted in the literature $[5,7]$. This, in turn, requires the collection of observations of such injuries in some cases for a long period of time, to conduct of thorough research [15].

The ERO injuries occurred in the following mechanisms: in 171,1 $(93,4 \%)$ cases there was impact of blunt solid objects on the neck and chest, in $11(6 \%)$ cases there was compression of the neck by hands or other blunt solid objects, in 1 $(0,5 \%)$ case - compression of the neck by hands and a loop.

The structures due to forensic medical examinations of ERO injuries were as follows. The damages of the costal skeleton of the chest occupied the first place - $161(87,9 \%)$ cases. Thus, fractures of several ribs occurred in 101 $(55,2 \%)$ observations, fractures of only one rib in $60(32,8 \%)$ observations. This followed by the damage to the larynx in closed blunt trauma of the neck (CBTN) - $16(8,6 \%)$ cases. The third place was occupied by $6(3,3 \%)$ cases of chest trauma without rib fractures. In 5 (2,7 \%) victims this category occurred contusion of lungs, complicated in $2(1.1 \%)$ cases of post-traumatic pneumonia, in $2(1,1 \%)$ cases by hemopneumothorax in one $(0,5 \%)$ case by hemothorax. In one $(0,5 \%)$ case rupture lungs complicated by hemothorax and posttraumatic pneumonia occurred.

At closed blunt trauma of the chest (CBTC) with fractures of the ribs, a contusion of the lungs or contusion of the lungs with rupture, was confirmed, using objective methods of investigation, in $7(3,8 \%)$ cases. However, in these injuries, hemothorax, pneumothorax or hemopneumothorax was present in $49(26,8 \%)$ cases. At the same time, hemopneumothorax was present in $31(16,9 \%)$ cases, of which in $25(13,8 \%)$ observations there were fractures of several ribs, in 6 $(3,3 \%)$ observations - fracture of one rib. Hemothorax was present in $8(4,4 \%)$ cases, of which in $6(3,3 \%)$ cases fractures of several ribs, in 2 $(1,1 \%)$ observations fracture of one rib were diagnosed. Pneumothorax occurred in $10(5,5 \%)$ observations, of which in $3(1,6 \%)$ cases fractures of several ribs, in $7(3,8 \%)$ cases fracture of one rib were present. 
In addition, in patients with fractures of the ribs and hemopneumothorax in 4 (2,2\%) cases, the experts noted acute respiratory failure (ARF), in $3(1,6 \%)$ cases - traumatic shock, in $7(3,8 \%)$ cases a posttraumatic pneumonia developed.

The changes noticed during the investigation of the character of injuries of the larynx at CBTN are presented in Table.

In all categories of victims there was an acute post-traumatic laryngitis. During $3(1,6 \%)$ examinations, in victims were diagnosed expert conclusions. In one $(0,5 \%)$ case, the victim had spot signs of posttraumatic pneumonia. In addition, severe injuries were present in $2(1,1 \%)$ cases of CBTC in the absence of rib fractures and hemopneumothorax, and in one $(0,5 \%)$ case of laryngeal injury with development of mechanical asphyxia.

It should be noted that in $8(4,4 \%)$ cases of establishment of severe bodily injuries by the experts, in CBTC, the presence of life-threatening phenomena listed in item 2.2.1 "o" "Rules", in

Characteristics of laryngeal injuries in cases of CBTN

\begin{tabular}{|c|c|c|c|c|c|c|}
\hline \multicolumn{3}{|r|}{ The character of the laryngeal injury } & \multicolumn{2}{|c|}{ quantity } & \multicolumn{2}{|c|}{$\%$} \\
\hline \multirow{2}{*}{ : } & \multirow{2}{*}{$\begin{array}{l}\text { Damage to the } \\
\text { cartilage of the larynx }\end{array}$} & Fracture of the plate of the thyroid cartilage & 1 & \multirow[b]{2}{*}{2} & 0,5 & \multirow[b]{2}{*}{1,0} \\
\hline & & $\begin{array}{l}\begin{array}{l}\text { Fracture of the plate of the thyroid and arch of the annular cartilage, laryngeal } \\
\text { hematoma, grade } 2 \text { stenosis }\end{array} \\
\end{array}$ & 1 & & 0,5 & \\
\hline \multirow{2}{*}{ 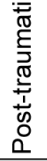 } & $\begin{array}{c}\text { Hemorrhage } \\
\text { (hematoma) in the } \\
\text { larynx }\end{array}$ & $\begin{array}{l}\text { Hemorrhage in the surrounding soft tissues of the larynx, paresis of its } \\
\text { muscles }\end{array}$ & 1 & 3 & 0,5 & 1,6 \\
\hline & & Hemorrhages in the vocal cords, their swelling & \multicolumn{2}{|c|}{4} & \multicolumn{2}{|c|}{2,2} \\
\hline \multicolumn{3}{|r|}{ The total number of observations of laryngeal injuries } & \multicolumn{2}{|c|}{16} & \multicolumn{2}{|c|}{8,6} \\
\hline
\end{tabular}

hemorrhages in the vocal cords, their swelling. In $4(2,2 \%)$ cases, the victims had a laryngeal hematoma, hemorrhage in the surrounding soft tissues. In $2(1,1 \%)$ cases in victims were present a fracture of one of the plates thyroid cartilage, while in one $(0,6 \%)$ victim was present closed fracture of arch cricoid cartilage with displacement fragments. In one $(0,5 \%)$ case, the victim had a fracture of the hyoid bone. Grade 1-2 stenosis of larynx was present in $3(1,6 \%)$ victims, while in one $(0,5 \%)$ case in victim with grade 2 laryngeal stenosis had the signs of grad 2 ARF. In one $(0,5 \%)$ case, the victim was diagnosed post-traumatic laryngeal muscle paresis. In one $(0,5 \%)$ case, laryngeal trauma was complicated by the development of mechanical asphyxia.

Severity of bodily injuries at forensic medical assessment by experts of traumas of ERO estimated the following. Severe injuries by the criterion "danger to life" "Rules ..." estimated by experts in $12(6,5 \%)$ cases of CBTC with fracture of several ribs and $2(1,1 \%)$ cases of trauma with fracture one rib. Meanwhile, in 12 $(6,5 \%)$ cases there was formation of a hemopneumothorax, in one $(0,5 \%)$ a hemothorax, and in one $(0,5 \%)$ a pneumothorax and a partial collapse of lungs. However, contusion of lungs or contusion with it rupture was established in 11 $(6 \%)$ cases. The presence of a complication of trauma in the form of moderate degree traumatic shock was noted in expert conclusions in one $(0,5 \%)$ case, severe degree in $2(1,1 \%)$ cases. As to the clinical signs, grade $1-3$ ARF as noted in $2(1,1 \%)$ particular ARF or traumatic shock of severe degree, was not specified in conclusions of experts. In $2(1,1 \%)$ cases, even when experts referred to the occurrence of life-threatening phenomena in the victims, their presence did not have a convincing scientific justification in expert conclusions, as required by the morphological and clinical approaches to forensic assessment of injuries $[1,3,14]$. Therefore, we believe that the degree of severity of injuries established by experts in these $10(5,5 \%)$ cases of CBTC is not sufficiently substantiated.

Moderate bodily injuries, by "absence of danger to life" and "health disorder duration" criterion more than 21 days, according to "Rules ...", were estimated by experts in $89(48,6 \%)$ cases of CBTC with fracture of several ribs, in $58(31,7 \%)$ case of fracture of the one rib. Meanwhile, hemopneumothorax was established in $19(10,4 \%)$ cases, pneumothorax in $9(4,9 \%)$ cases, hemothorax in $7(3,8 \%)$ cases. In addition to the damage of moderate degree of bodily injuries of same criterions by experts assigned: $2(1,1 \%)$ cases of CBTC with contusion of the lungs which in one case was complicated by development of hemothorax $(0,5 \%)$, in one $(0,5 \%)$ case - by posttraumatic pneumonia; one $(0,5 \%)$ case - by CBTC with rupture of the lung and development of hemothorax; one $(0,5 \%)$ case - by CBTN with the formation of cricoid and thyroid larynx cartilages fractures.

In these forensic medical examinations, experts tried to confirm the duration of the disorder of 
health by results of objective research methods, by dynamics of pathological changes. However, in conclusions of $3(1,6 \%)$ examinations, in one $(0,5 \%)$ victim with CBTN and in two $(1,1 \%)$ victims with CBTC, ARF was observed. In these cases, it was still possible to qualify the injuries in the victims as severe bodily injuries according to the criterion of "danger to life", in accordance with paragraph 2.1.3 "o" of the "Rules";

Light injuries that caused a short-term health disorder were estimated: in one $(0,5 \%)$ case the CBTC with lung contusion, absence rib damage and development of post-traumatic pneumonia, in 9 (4,9\%) cases CBTN with injury larynx, accompanied by acute posttraumatic laryngitis were observed. At the same time, in patients with CBTC in $3(1,6 \%)$ cases there was laryngeal hematoma, $2(1,1 \%)$ patients has formed grade $1-2$ laryngeal stenosis, in one $(0,5 \%)$ victim paresis muscles of the larynx. $2(1,1 \%)$ victims had hemorrhages in the vocal cords of the larynx. One $(1,1 \%)$ victim had a fracture of the hyoid bone. However, in 2 $(1,1 \%)$ cases of CBTN with damage to the larynx in the presence of grade 1-2 stenosis, it would be possible to identify and justify the clinical signs of ARF, which would give grounds for experts to classify these injuries as severe injuries, according to the criterion "danger to life", in accordance with paragraph 2.1.3 "o" of the "Rules...".

Light injuries were estimated by experts in 5 $(2,7 \%)$ observations of laryngeal injuries with development of acute posttraumatic laryngitis. In these cases, the experts did not have sufficient data on the final results of laryngeal injuries necessary for the forensic assessment of the examined injury. Additional control diagnostic tests, in particular stroboscopy of the larynx, phoniatric examination by experts during the examinations were not conducted. In these cases, in the absence of information about the final results of the injury and the inability of experts to conduct additional investigations, it was necessary to abandon the determination of the severity of these injuries.

The analysis of the available expert materials allowed establishing that the medical documentation provided to the experts does not always detect and correctly treat laryngeal cartilage damage with the presence of their fractures. In medical institutions and during examinations, computed tomography was not always performed, which allows to detect fractures of the laryngeal cartilage. At the same time, some scientific papers emphasize the importance of this study in such injuries $[4,8,16]$. Experts do not always detect signs of ARF, which makes it impossible to determine the danger to the life of the victim and, accordingly, to correctly determine the severity of the injuries. A clear definition of the signs of ARF requires the use of morphological and clinical approaches in assessing the severity of injuries [3]. The victims are not always referred by experts to a specialized hospital, to conduct additional diagnostic tests, including those which allow determining the degree of impaired function of the damaged organs and the consequences of their damage.

\section{Conclusions}

1) At carrying out forensic medical examinations of ERO traumas, cases of damages of a costal skeleton of the thorax prevailed (87,9\% of cases). Damage of cartilaginous skeleton of the larynx were present only in $1,0 \%$ of cases. Substantiation of the presence of clinical signs of danger to life due to injury is the most difficult issue in cases of such examinations for forensic medical experts.

2) Annually, $0.5 \%$ of forensic medical expert conclusions are examinations of victims with ERO injuries.

3) According to experts' evaluation of ERO blunt trauma, severe bodily injuries were estimated in 9,3\% of cases, in the occurrence of life-threatening phenomena, namely ARF, traumatic shock, mechanical asphyxia. Moderate bodily injuries were estimated in $82,5 \%$ of cases, mainly in injuries with fractures of the ribs and cartilage of the larynx, in the absence of danger to life. $8,2 \%$ of cases of CBTC, in the absence of rib fractures and laryngeal injuries, with the occurrence of posttraumatic inflammation, were classified as light injuries.

4) Forensic medical expert assessment of ERO blunt trauma could let both underestimation and overestimation of the severity of injuries, which is connected with lack of a unified scientific and methodological approach of such examinations.

5) The prospect of further research is to unify the morphological and clinical approaches in determining the severity of injuries in ERO trauma, on the basis of continuing scientific work, to establish all possible clinical and morphological manifestations of such trauma.

\section{Declarations:}

\section{Statement of Ethics}

The authors have no ethical conflicts to disclosure.

\section{Consent for publication}

All authors give their consent to publication.

\section{Disclosure Statement}

The authors have no potential conflicts of interest to disclosure.

\section{Funding Sources}

This study was not supported by any grants from public, commercial or other sectors

\section{Data Transparency}

The data can be requested from the authors. 


\section{References}

1. Mykhailychenko BV, Kikinchuk VV, Peshenko OM. (2020) Sudova ekspertolohiia (sudova medytsyna): navchalnyi posibnyk [Forensic medical expertise (forensic medicine): a textbook]. Kyiv, Kharkiv: "Vydavnytstvo Liudmyla". 396 s. [in Ukrainian].

2. Pravyla sudovo-medychnoho vyznachennia stupenia tiazhkosti tilesnykh ushkodzhen [Rules for forensic medical assessment of bodily injuries severity]. Nakaz MOZ Ukrainy №6 vid 17.01.1995 r. "Pro rozvytok ta vdoskonalennia sudovo-medychnoi sluzhby Ukrainy". Kyiv, 1995; 220 s. [in Ukrainian].

3. Holubovych LL, Olkhovskyi VO, Herasymenko OI. (2021) Osnovy sudovoi medytsyny: navchalnometodychnyi posibnyk [Bases of forensic medicine: Textbook]. Kharkiv: FOP Brovin O.V. 536 s. [in Ukrainian].

4. Rash W. (2011) Hyoid / Thyroid Fracture. Journal of Emergency Nursing. 37 (2): 182-183.

5. Stewart ME, Erath BD (2020) Investigating Blunt Force Trauma to the Larynx : the role of inferiorsuperior vocal fold displacement on phonation Journal of Biomechanics. 10: 1-28

6. Tachiev OV. (2018) Analiz sudebno-meditsinskih ekspertiz v sluchayah travm organov grudnoy kletki, oslozhnivshihsya malyim gemotoraksom pri ne smertelnyih sluchayah (DTP, padenii, razlichnyih fizicheskih vozdeystviyah) po dannyim otdela sudebno-meditsinskih ekspertiz poterpevshih, obvinyaemyih i drugih lits za 2013-2017 gg [Analysis of forensic examinations in cases of chest injuries complicated by small hemothorax in non-fatal cases (accidents, falls, various physical impacts) according to the department of forensic examinations of victims, accused and others for 2013-2017]. Zb-k m-lov: mezhdunarodnogo kongressa i nauchno-prakticheskoy shkolyi "Aktualnyie voprosyi sudebnoy meditsinyi i ekspertnoy praktiki 2018"; 2018 aprel 18-20; M. s. 39. [in Russian].

7. Abakumov MM. (2013) Mnozhestvennyie i sochetannyie raneniya shei, grudi, zhivota [Multiple and combined injuries of the neck, chest, abdomen]. M .: Binom. 687 s. [in Russian].

8. Feng AL, Parikh A., Gadkaree SK, Naunheim MR, Song PC (2020) Laryngeal fractures in professional and semiprofessional ice hockey players. Laryngoscope Investigative Otolaryngology. 5: 1110-1116.

9. Sethi RKV, Khatib D, Kligerman M, Kozin ED, Gray ST, Naunheim MR. (2019) Laryngeal fracture presentation and management in United States emergency rooms. Laryngoscope. 129 (10): 2341-2346.

10. Viejo-Moreno R, Garcia-Fuentes C, Mudarra-Reche C, Terceros-Almanza LJ, Chico-Fernandez M. (2019) Laryngeal injury in closed cervical traumatism. Med. Intensive. 43: 503-507.

11. Khodaee M, Waterbrook AL, Gammons M. (2020) Sports related fractures, dislocations and trauma. Switzerland Springer. 1020 p.

12. Ikonnikova DI, Tumanov EV. (2018) Sravnitelnyiy analiz meditsinskih kriteriev tyazhesti vreda, prichinennogo zdorovyu cheloveka pri zakryitoy travme organov grudnoy polosti v rossiyskoy federatsii i stranah postsovetskogo prostranstva [Comparative analysis of medical criteria for the severity of harm caused to human health in closed trauma of the thoracic cavity in the Russian Federation and the postsoviet space] Zb-k m-lov: mezhdunarodnogo kongressa i nauchno-prakticheskoy shkolyi "Aktualnyie voprosyi sudebnoy meditsinyi i ekspertnoy praktiki - 2018"; 2018 aprel 18-20; M. s. 33-34. [in Russian].

13. Kolkutin VV., Sosedko YuI. (2002) Sudebno-meditsinskaya ekspertiza povrezhdeniy u zhivyih lits [Forensic examination of injuries in living persons.]. M. s. 9-39. [in Russian].

14. Devyatkin AE, Vinnik NI, Chernyak VV. (2017) Sudebnaya meditsina: uchebn. posob [Forensic medicine: textbook]. Poltava: VGUZU "UMSA". 116 s. [in Russian].

15. Balci AE, Eren N, Eren S, Ulku R. (2002) Surgical treatment of post-traumatic tracheobronchial injuries: 14-year experience. European Journal of Cardio-Thoracic Surgery. 22 (6): 984-989. https:// doi.org/10.1016/S1010-7940(02)00591-2

16. Mercer SJ, Jones CP, Bridge M, Clitheroe E, Morton B, Groom P. (2016) Systematic review of the anesthetic management of non-iatrogenic acute adult airway trauma. British Journal of Anesthesia. 117 (S1): i49 - i59.

Received: 03-Mar-2020

Accepted: 13-Jun-2020 